\title{
Nutcracker Syndrome and Sickle Cell Trait
}

\author{
Sean Verma, MD, Mustafa Khaliqi, MD, and Kellee L. Oller, MD \\ University of South Florida Internal Medicine Residency Program, University of South Florida, Tampa, FL, USA.
}

$\mathrm{J}$ Gen Intern Med 32(11): 1171

DOI: $10.1007 / \mathrm{s} 11606-017-4156-1$

(C) Society of General Internal Medicine 2017

$\mathrm{T}_{\mathrm{o}}$

We read with great interest the report of an uncommon etiology of hematuria: nutcracker syndrome in a patient with sickle cell trait. ${ }^{1}$ It would be remiss to not mention renal medullary carcinoma, which may present similarly with abdominal pain and hematuria in a patient with sickle cell trait. Renal medullary carcinoma, first described in 1995, occurs almost exclusively in patients with sickle cell trait. ${ }^{2}$ Symptoms of hematuria, flank or abdominal pain, and weight loss may herald the unfortunate condition. Contrast-enhanced computed tomography (CT) or magnetic resonance imaging (MRI) can identify the heterogeneous infiltrative mass. ${ }^{3}$ Given the prevalence of sickle cell trait in the African American population, it is imperative to include renal medullary carcinoma in the differential diagnosis of patients presenting with hematuria.

Corresponding Author: Sean Verma, MD; University of South Florida Internal Medicine Residency ProgramUniversity of South Florida, 5 Tampa General Circle, HMT 750, Tampa, FL 33606, USA (e-mail: sverma4@health.usf.edu).

\section{Compliance with Ethical Standards:}

Conflict of Interest: The authors have no conflict of interst to disclose.

\section{REFERENCES}

1. Ahmad A, McElwee SK, Kraemer RR. Nutcracker syndrome and sickle cell trait: a perfect storm for hematuria. J Gen Intern Med 2017. doi:10. 1007/s11606-017-4008-z.

2. Alvarez O, Rodriguez MM, Jordan L, Sarnaik S. Renal medullary carcinoma and sickle cell trait: a systematic review. Pediatr Blood Cancer 2015;62(10):1694-9. doi:10.1002/pbc.25592.

3. Shi Z, Zhuang G, You R, Li Y, Li J, Cao D. Clinical and computed tomography imaging features of renal medullary carcinoma: a report of six cases. Oncol Lett 2016;11(1):261-6. doi:10.3892/ol.2015.3891. 